\title{
12. SEM MICROSTRUCTURAL ANALYSIS OF A VOLCANOGENIC SEDIMENT COMPONENT IN A TRENCH-SLOPE BASIN OF THE CHILE MARGIN ${ }^{1}$
}

\author{
Kari Strand ${ }^{2}$
}

\begin{abstract}
During Ocean Drilling Program (ODP) Leg 141, Pliocene to Pleistocene forearc sediments of the Chile margin were recovered near latitude $46^{\circ} \mathrm{S}$ in the vicinity of the Chile spreading ridge-trench collision. The sediments largely represent deposition from slope failures, turbidity currents, and suspension processes in basin plain/trench to slope apron environments. SEM microstructural analysis of some glassy volcaniclastic grains shows a mixed provenance of Andean volcanic-arc- and some forearc-derived volcaniclastics with a distribution that is related to the evolutionary events that occur during spreading-ridge subduction, the glacially influenced sediment input and the transportational mechanisms, including turbidity currents.

The cessation of arc volcanism during progressive spreading-ridge subduction could be inferred from the observation that the volcanogenic component in the sediments is more abundant throughout the Pliocene-lower Pleistocene sandy portions and is lacking or more restricted during the upper Pleistocene. The evolved, silicic, vesicle-rich clast component is abundant upsection in the Pleistocene record, mostly concentrated in the sandy turbidites. The deposition of sparse pumiceous lapilli-ash layers at the present sites from powerful explosive activity is probably more related to the direction of the winds than to the evolution of the arc volcanism, which may have been due to spreading-ridge subduction, whereas the abundant thin basalt to basaltic andesite ash layers at Taitao Ridge indicate quench-fragmentation during anomalous subaqueous near-trench volcanism related to spreadingridge subduction and incipient rifting along the Taitao Fracture Zone.
\end{abstract}

\section{INTRODUCTION}

A record of explosive volcanism on land and volcano-tectonic events are assumed to be readable from the distribution of ash and resedimented volcaniclastics in deep-sea sediments (e.g., Bitschene et al., 1989; Desprairies et al., 1989; Pouclet et al., 1990; Fujioka et al., 1992; Nishimura et al., 1992; Rodolfo et al., 1992). This paper deals with the nature of volcanogenic sediment components in forearc-basin strata collected near the Chile margin Triple Junction, at which the Chile Ridge, the spreading boundary between the Nazca and Antarctic Plates, meets the Chile Trench. Main objectives of the Ocean Drilling Program (ODP) Leg 141 focused on the effects of spreading-ridge subduction assuming to produce rapid uplift and subsidence of the arc and forearc, a cessation of arc magmatism, anomalous near-trench and forearc magmatism and localized subsidence and extensional deformation of the forearc in the region of the collision (Marshak and Karig, 1977; Cande and Leslie, 1986; Cande et al., 1987).

Scanning electron microscope (SEM) microstructural analysis of volcanic glass is proposed as a possible means for evaluating (1) the style of explosive volcanism and the fragmentation mechanism of ancient volcanic eruptions; (2) the effects of transportation and deposition of primary volcanogenic sediments from eruptions onland as reworked and resedimented volcaniclastics in the marine environment; and (3) the stage of alteration (e.g., Wohletz, 1983; Heiken and Wohletz, 1985). Volcanogenic components in sediments recovered on Leg 141 are studied in order to (1) ascertain any early effects of the cessation of arc volcanism related to spreading-ridge subduction (e.g., Cande and Leslie, 1986); (2) understand the distribution, characteristics and origin of the secondary volcaniclastic material and distinct primary fall-out ash layers, their depositional environment and transportation in a trench slope setting; and (3) show the distribu-

\footnotetext{
${ }^{1}$ Lewis, S.D., Behrmann, J.H., Musgrave, R.J., and Cande, S.C. (Eds.), 1995. Proc ODP, Sci. Results, 141: College Station, TX (Ocean Drilling Program).

${ }^{2}$ Department of Geology, University of Oulu, Linnanmaa, SF-90570 Oulu, Finland.
}

tion and character of the ash derived from intra-basinal subaqueous near-trench volcanism related to ridge subduction (e.g., Marshak and Karig, 1977),

\section{METHODS}

The volcanic glass component in the coarse-grained fraction $(>0.063$ $\mathrm{mm}$ ) of the bulk samples was examined by grain counting under a stereomicroscope. The bulk samples were also impregnated to obtain a total of 73 thin sections for petrographic analysis. The nomenclature and methods of sample treatment and SEM microstructural analysis are adopted from Heiken (1974) and Heiken and Wohletz (1985). After oven drying and treatment with a hexametaphosphate dispersant, each unlithified sample was wet-sieved into a fine fraction $<0.063 \mathrm{~mm}$ and a coarse fraction $>0.063 \mathrm{~mm}$. After drying, accelerated with acetone, the sand fraction was investigated with a JEOL, JEM-100CX II TEM and a JEOL, JSM-6300 FESEM to document the microstructures of typical volcanogenic components and with a JEOL, JSM-6400 SEM with EDS to determine the major-element chemical composition of single sand-size glass fragments for both primary and secondary volcaniclastics from polished thin sections. Operating conditions were 15 $\mathrm{kV}$ with beam current of $17.1 \mathrm{nA}$ and $100 \mathrm{~s}$ count time. The SEM/EDS was chosen as an analytical instrument rather than an electron microprobe (EM) because some loss of alkalis under the beam can easily occur when studying volcanic glass fragments by EM. The analytical precision of SEM/EDS work are not as good, but the instrument is more sensitive to the important alkalis. A total number of 52 chemical analyses were performed on vitric volcaniclastic fragments and pyroclasts, and their compositions were plotted on the Total Alkali-Silica diagram (TAS) of IUGS for common volcanic rocks (Le Bas et al., 1986, 1992) and the $\mathrm{K}_{2} \mathrm{O}-\mathrm{SiO}_{2}$ variation diagram of Peccerillo and Taylor (1976).

\section{STUDY AREA}

Sites 859,860 , and 861 were investigated as part of the northern transect from the base of the trench slope across the middle and upper slope about $40 \mathrm{~km}$ north of the Chile margin Triple Junction near latitude $46^{\circ} \mathrm{S}$, whereas Site 863 was drilled into the base of the trench slope over the actual subducted rift axis at a position approximately 


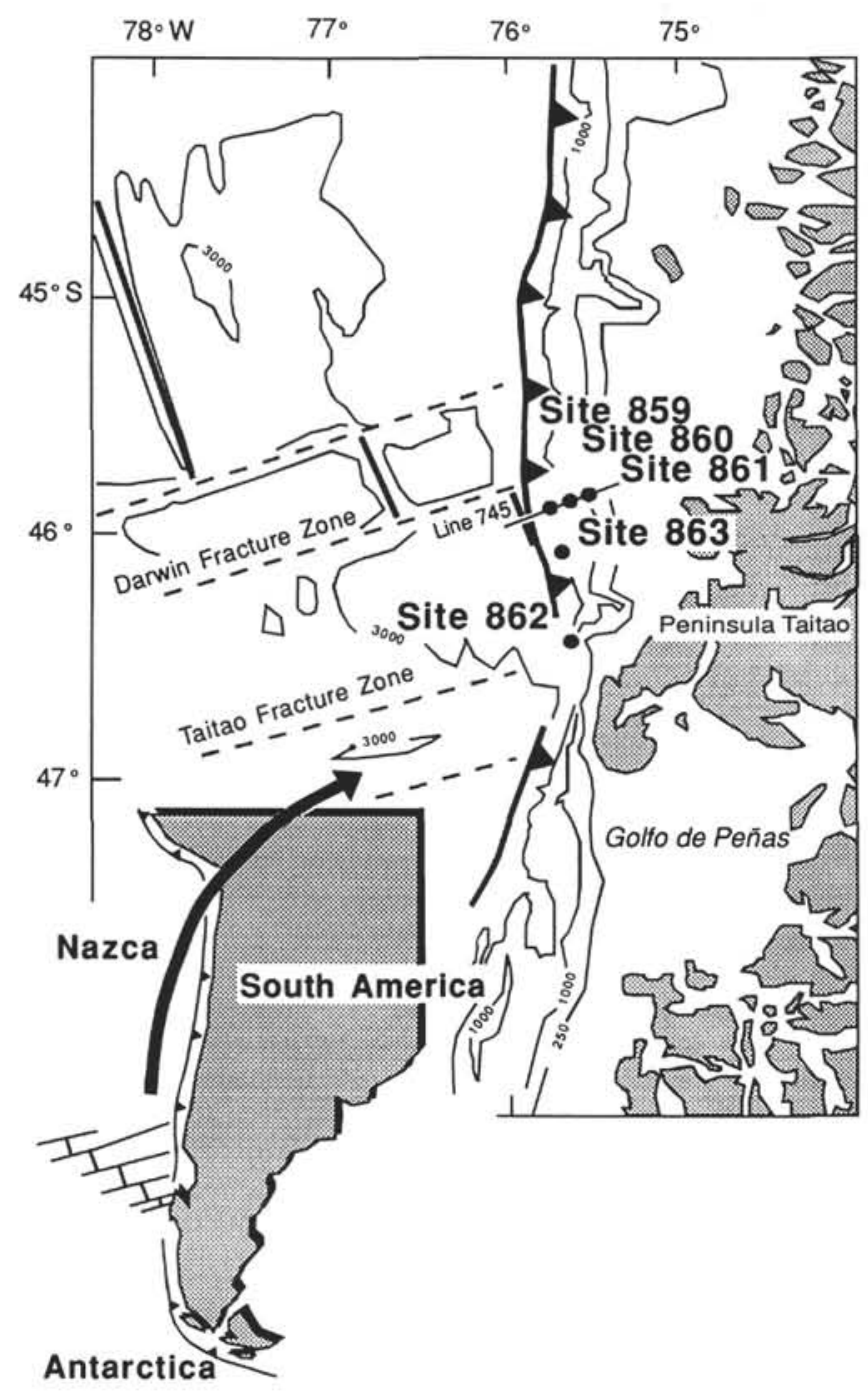

Figure 1. Map showing the main bathymetric and tectonic features of the Chile margin in the vicinity of the Chile Triple Junction, the location of Seismic Line 745 and Sites 859 to 863 .

on strike with Site 859 (Figs. 1 and 2). The northern transect provides a lithological characterization of the margin at a stage prior to ridge collision, whereas Site 863 represents the place where ridge collision had occurred approximately $50 \mathrm{ka}$ ago (Bangs et al., 1992). Site 862 is located near the crest of a bathymetric high, the Taitao Ridge, approximately $25 \mathrm{~km}$ south of the present location of the Chile margin Triple Junction above the trace of the Taitao Fracture Zone (Fig. 1). The Taitao Ridge was drilled to compare the evolution of the ridge with that of the Pliocene-aged Taitao Ophiolite on the Taitao Peninsula (Shipboard Scientific Party, 1992d). The Taitao Ridge may represent a fragment of oceanic ridge segment in the process of emplacement into the Chile margin or an incipient rift propagated into the forearc over the site of ridge collision (Forsythe and Prior, 1992).

\section{TRENCH-SLOPE SEDIMENTS NEAR THE CHILE TRIPLE JUNCTION}

The principal sedimentary facies types of the Leg 141 clastic deposits and their interpretation are shown in Table 1. Eight sedimentary facies are distinguished based on grain size and sedimentary structures. In some cores the lag in the structures due to coring disturbances make it difficult to distinguish any sedimentary facies, but in many others preservation is good enough to permit facies distinction.

\section{Northern Transect (Sites 859, 860, 861) and Site 863}

\section{Description}

The uppermost part of Site 859 (Unit I, $0-10$ mbsf) is made up predominantly of laminated to mottled clayey silt and silty clays (Facies 5 and 8 ) and contains abundant microfossils of late Pleistocene age (Shipboard Scientific Party, 1992a). Uniform Pleistocene and upper Pliocene clayey silts and silty clays make up Subunit IIA (10-235 mbsf). Subunit IIB extends to a depth of $476 \mathrm{mbsf}$ and consists of upper Pliocene silty claystones and clayey siltstones associated with some degree of tectonic thickening (Shipboard Scientific Party, 1992a). The dominant sedimentary facies in Unit II are Facies 5, 6, and 8, occasionally interbedded with Facies 4 in the upper part. Site 860 is divided into three lithological units (Shipboard Scientific Party, 1992b). Unit I consists of $87.7 \mathrm{~m}$ of clayey silt to silty clay (Facies 8 ) with nannofossils ranging in age from the late Pliocene to Pleistocene and graded silt and sand interbeds (Facies 3 and 4). Unit II (87.7-242.5 mbsf) is of early Pliocene to late Pliocene age with facies that include claystone to silty claystone (Facies 6 and 7) and also sandstone (Facies 3 ) and thin conglomerate beds (Facies 2). Subunit IIIA (242.5-309.8 mbsf) consists of early Pliocene to late Pliocene clayey siltstones (Facies 5 to 6 ), silty claystones with nannofossils (Facies 8), disorganized sandy silty claystones with dispersed pebble to granule-sized lithic clasts (Facies 1), and thin conglomerate beds (Facies 2). Subunit IIIB occurs between $309.8 \mathrm{mbsf}$ and the bottom of the hole at $617.8 \mathrm{mbsf}$, with similar lithologies to IIIA but repeated in three intervals (Shipboard Scientific Party, 1992b). Three lithological units were identified at Site 861 (Shipboard Scientific Party, 1992c). Unit I (0-43.8 mbsf) consists of Quaternary silty clays and clayey silts, containing some nannofossils (Facies 8). Subunit IIA (43.8-208.9 mbsf) contains silty clays and clayey silts of late Pliocene and Pleistocene age with intercalations of graded silt, sand (Facies 3 and 4), and matrix to clast-supported gravel layers (Facies 2). Subunit IIB (208.9-351.9 mbsf) has similar lithologies in more lithified form. Unit III (351.9-496.3 mbsf) consists of silty claystone to clayey siltstone.

Site 863 consists of two lithological units differing to some extent from the lithological units of the northern transect. Subunit IA $(0-46.6$ mbsf) is composed of $4 \mathrm{~m}$ of Quaternary silty clay to clayey silt overlying upper Pleistocene silty clay to clayey silt, with minor sand. Subunit IB (46.6-104.4 mbsf) consists of similar upper Pleistocene lithologies but are more lithified. Unit II (104.4 to $742.9 \mathrm{mbsf}$ ) is composed of lower and upper Pleistocene sandstone and bioturbated siltstone (Facies 3 and 4) with silty claystone (Facies 5). Most bedding in Unit II is steep to vertical.

\section{Interpretation}

Site 859 and the uppermost part of Site 860 are dominated by hemipelagic sedimentary processes (Facies 8 ) and fine-grained (Facies 5) to mud turbidites (Facies 6). Sandy portions (Facies 3 and 4) are defined as high to low-density distal turbidites (e.g., Pickering et al., 1986). The graded sand-silt couplet (Facies 4) is consistent with incomplete Bouma sequences. Unit II of Site 860 is characterized by mud-turbidite deposition (Facies 6 and 7), while Unit III is characterized by at least 4 repetitions of high-density to low-density finegrained turbidites overlain by hemipelagic intervals, probably the result of imbrication by thrust faults. The deposition of Unit II sediments of Site 861 was in an environment closer to the source. Silty claystone to clayey siltstone in Unit III reflect fine-grained turbiditic and hemipelagic deposition. Most sediments of the northern transect represent deposition from slope failures, turbidity currents and suspension processes, much resembling a situation described by Underwood and Backman (1982) in a trench-slope. The depositional envi- 

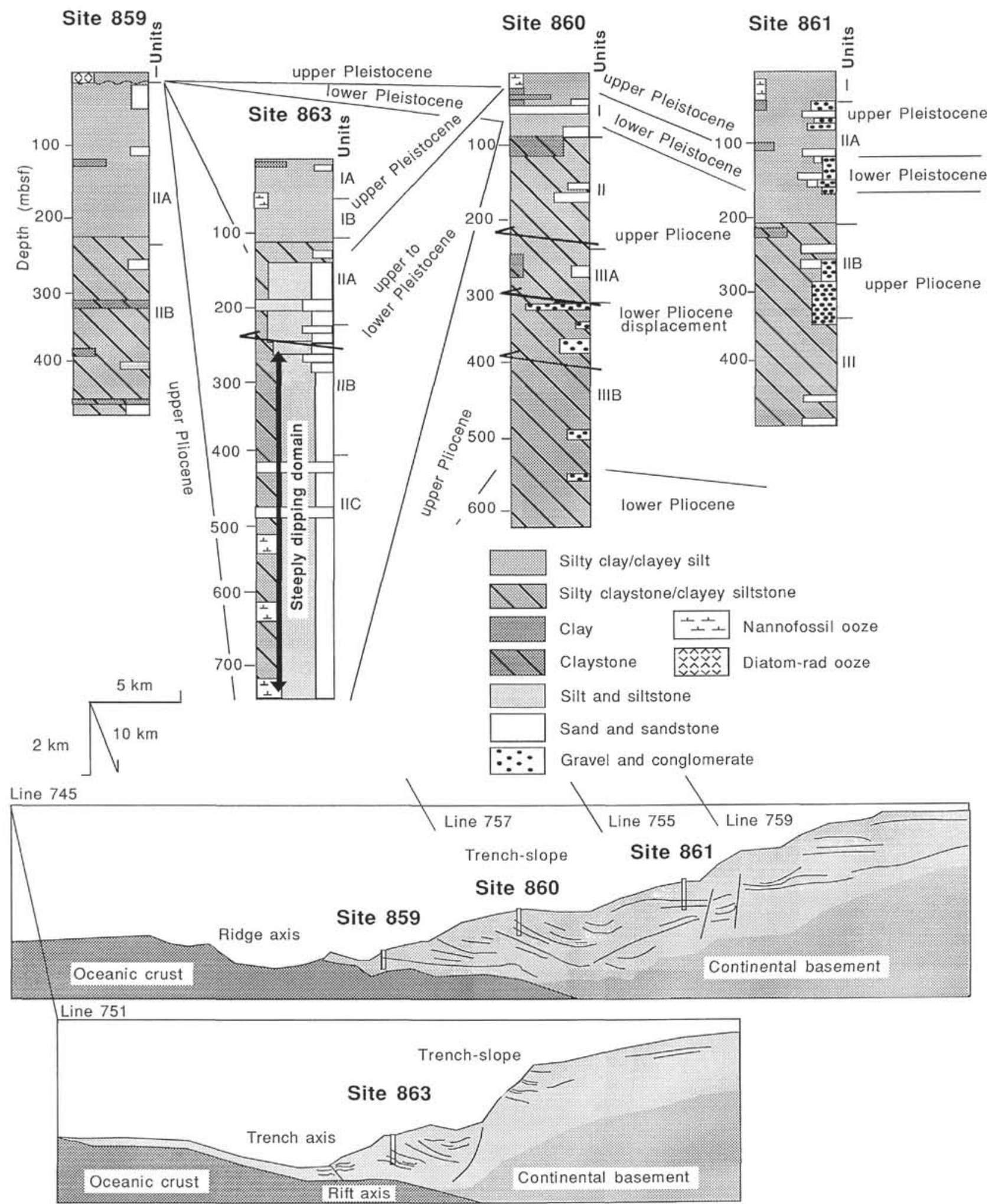

Figure 2. Graphic lithologies and stratigraphic correlation for Sites 859-861 and 863, and cross sections of the Chile margin along Seismic Lines 745 and 751 .

ronments range from basin plain/trench and slope aprons associated with hemipelagic deposits (Strand et al., this volume).

Most of the Site 863 Unit II sediments are interpreted as turbidite sands, silts and clays that are largely similar to modern submarine canyon-fed fan deposits farther north in the trench (Thornburg and Kulm, 1987a; Thornburg et al., 1990), whereas Unit I is interpreted to have been more likely deposited by slope apron processes. The slope aprons generally include coarse to fine-grained turbidites and hemipelagites, slides and debrites (Pickering et al., 1986, 1989). The Unit II consists predominantly of partial Bouma sequences; the beds generally lack the basal or middle parts of a Bouma sequence (Shipboard Scientific Party, 1992e). The only large canyon that may have 
Table 1. Summary of facies types used for Leg 141 sediments.

\begin{tabular}{|c|c|c|}
\hline Facies & Characteristics & Interpretation \\
\hline 1: Disorganized sandy-silty-clay (diamict) & $\begin{array}{l}\text { Granule to pebble-sized clasts dispersed in fine-grained } \\
\text { matrix: inverse to normal graded: bed thickness } 0.8-1.5 \mathrm{~m}\end{array}$ & Debris flow or high-density fine-grained turbidity current \\
\hline 2: Gravel & Matrix-supported to clast-supported gravel or conglomerate & Debris flow \\
\hline 3: Graded to massive sand & Thin beds of poorly sorted sandor sandstone & High-density turbidity current or grain flow \\
\hline 4: Graded sand-silt couplet & $\begin{array}{l}\text { Couplet composed of a basal sandy unit and massive to } \\
\text { laminated fine-grained sediment }\end{array}$ & Low-density turbidity current \\
\hline 5: Laminated to layered silty clay to clayey silt & $\begin{array}{l}\text { Fine-grained sediment showing layering and thin silt-rich } \\
\text { horizontal beds }\end{array}$ & $\begin{array}{l}\text { Fine-grained turbidity current or traction transport by bottom- } \\
\text { current }\end{array}$ \\
\hline 6: Laminated to massive clay to silty clay & Fine-grained showing fine laminae or structureless & Mud turbidity current \\
\hline 7: Deformed clay to silty clay & $\begin{array}{l}\text { Fine-grained sediment showing soft sediment folds, wispy } \\
\text { laminae }\end{array}$ & Mudflow or slump \\
\hline 8: Mottled silty clay to clayey silt & $\begin{array}{l}\text { Fine-grained sediments with various proportions of siliceous } \\
\text { and calcareous microfossils; sometimes bioturbated }\end{array}$ & Hemipelagic sedimentation \\
\hline
\end{tabular}

contributed sediment to Site 863 is located to the southeast, probably too far away to have been a major feeding channel for the sediments deposited along the northern transect (Sites 859-861).

\section{Taitao Ridge (Site 862)}

\section{Description}

The 22-m-thick sediment succession (Unit I), of upper Pliocene to Quaternary age, overlies intercalated submarine basalt, dacite, and rhyolite flows of Unit II (Shipboard Scientific Party, 1992d). Subunit IA is some $6 \mathrm{~m}$ thick and consists of silty clay to clayey silt, clay, and graded to laminated silty fine sand (Facies 4 and 5). Some sandy intervals are cross-laminated. Subunit IB (6-21 mbsf) represents an increase in lithification of the same materials as in Subunit IA, and Subunit IC (21-22 mbsf) represents the same lithology as Subunit IB but is associated with hydrothermal alteration. The matrix-supported conglomerate observed in Hole $862 \mathrm{~A}$ probably represents the basal lithology overlying the major volcanic sequence.

\section{Interpretation}

Site 862 Unit I represents the thin sediment cover that blankets the Taitao Ridge. The graded intervals in Subunit IA represent deposition from distal low-density turbidity currents, mostly in the form of suspension fallout. The cross-laminated sandy intervals may represent contourites or may have been produced by currents generated by contemporaneous submarine near-trench eruptions. Unit II represents in-situ, but highly fractured, pillowed flow-units composed of a bimodal suite of basaltic and dacitic to rhyolitic eruptive materials (Shipboard Scientific Party, 1992d).

\section{VOLCANOGENIC SEDIMENT RECORD}

The sediments of Leg 141 all have a significant volcanogenic component, and some sandy beds consist of up to $20 \%-35 \%$ glassy volcanic material. The Site 862 sediments consist of $5 \%-40 \%$ volcanic glass particles. The diagenetic alteration of glass may be a significant process leading to the disappearance of volcanogenic particles in general, but it has little influence on the Leg 141 sediments, major alteration of glass having occurred only in the lowermost units at Site 863 (Shipboard Scientific Party, 1992e, Prior et al., this volume). Two major components of volcanogenic material were found in the trench-slope basin sites: (1) secondary volcaniclastic sands and siltstones ( $>15 \%$ vitric ash grains) and (2) volcanic ash beds (i.e., "marine ash layers") of two major modes: light-colored pumiceous layers up to $10 \mathrm{~cm}$ thick (Sites 859-861 and 863) and thin black vitric ash layers in the Taitao Ridge (Site 862). The volcaniclastic grain distribution in the coarse sediments is related to the sediment source characteristics, sedimentary transport, and depositional environment.

\section{The Secondary Volcaniclastic Sediment Component}

SEM microstructure analysis demonstrates the presence of six types (I-VI) of volcanic glass (PI. 1, Figs. 1-6), according to morphology, degree of vesicularity, color, and chemical composition. Some general variations in the concentrations of these types of volcanic glass between the coarse clastics at each drill site are shown in Table 2. The coarse-grained sediments consist of highly vesicular colorless pumice fragments of varying abundance (Type I; Pl. 1, Figs. 1 and 2), vesicular particles ranging in color from colorless-light brownish to brownish (Type II and Type III; PI. 1, Figs. 5 and 6), and slightly vesicular brownish (Type IV) to brownish-blackish, blocky with few vesicles (Type V; Pl. 1, Fig. 4), or no vesicles (Type VI). The pumiceous to reticulate fragments are always colorless or slightly brownish. The flat to cuspate bubble wall and bubble junction shards were classified as being of the vesicular type and were distinguished by their color. Some glass fragments are microlitic with a brownish color, possessing few vesicles or blocky forms (Pl. 1, Fig. 4).

The vesicle-rich clast component (Type I and Type II) is abundant upsection in the Pleistocene record, mostly concentrated in the sandy turbidites (Table 2). This is particularly apparent in Sites 860 and 863 , at the same time as brownish to blackish blocky volcanic grains (Type $\mathrm{V})$ become more abundant downhole. The upper Pliocene record in Site 860 is rich in brownish to blackish slightly vesicular to blocky volcanic grains with few vesicles (Types IV and V). According to the smear slide database for the Leg 141 coarse clastics, the overall volcaniclastic component in the sediments is more abundant throughout the Pliocene to lower Pleistocene sandy portions and is absent or more restricted during the upper Pleistocene.

The primary fragmentation of volcanic glass grains was caused by magmatic explosions. Some primary fragmentation may have occurred due to hydrovolcanism, but products of that kind are generally more local. Hydrovolcanism generally generates glass shards which are more blocky and less vesicular than those formed magmatically (Heiken 1972; Wohletz 1983). The vesicular to highly vesicular types of glass are particles that were first transported subaerially to both subaerial and submarine site and then mixed with other sedimentary debris and finally deposited in their present location by dense turbidity currents or as debris flows (e.g., Fisher, 1984; Cas and Wright, 1987). This is indicated by the textures of the glass types, which are characteristic of highly explosive (e.g., Plinian) eruptions (Walker, 1973; Wright et al., 1980; Heiken and Wohletz, 1985).

\section{Major-element Composition of the Volcaniclastic Grains}

The range in composition of individual volcanic glass grains is from basaltic andesite to rhyolite (Table 3 and Fig. 3). All are related to the calc-alkaline fractionation series with moderate $\mathrm{K}_{2} \mathrm{O} \%$ (Fig. 3). The colorless bubble-wall glasses are dacite to rhyolite $\left(\mathrm{SiO}_{2}=63 \%-\right.$ $71 \%)$ and those of light brownish are basaltic andesite $\left(\mathrm{SiO}_{2}=52 \%-\right.$ 
Table 2. Types of volcanic glass grain counted as vol\% from the volcanogenic sediment component of the sand-sized fraction $(>0.063 \mathrm{~mm})$ of Leg 141 coarse sediments.

\begin{tabular}{|c|c|c|c|c|c|c|c|c|c|}
\hline $\begin{array}{l}\text { Core, section. } \\
\text { interval }(\mathrm{cm})\end{array}$ & $\begin{array}{l}\text { Depth } \\
\text { (mbsf) }\end{array}$ & I & II & III & IV & V & VI & $\begin{array}{l}\text { Total } \\
\text { count }\end{array}$ & Comments \\
\hline $\begin{array}{l}141-859 \mathrm{~A}- \\
\quad 11 \times-4,66-68\end{array}$ & 73.46 & 1.0 & 35.0 & 28.1 & 18.2 & 13.8 & 3.9 & 200 & Fine silty sand consentrations in silty clay \\
\hline $\begin{array}{l}141-859 \mathrm{~B}- \\
4 \mathrm{R}-2,67-69 \\
16 \mathrm{R}-4,13-15\end{array}$ & $\begin{array}{l}142.17 \\
259.2 .3\end{array}$ & $\begin{array}{l}3.2 \\
4.7\end{array}$ & $\begin{array}{l}14.9 \\
21.2\end{array}$ & $\begin{array}{l}20.0 \\
43.0\end{array}$ & 20.5 & $\begin{array}{l}35.8 \\
15.6\end{array}$ & $\begin{array}{l}5.6 \\
1.4\end{array}$ & $\begin{array}{l}200 \\
200\end{array}$ & $\begin{array}{l}\text { Structureless clayey silt } \\
\text { Massive silty sandstone bed }\end{array}$ \\
\hline $\begin{array}{l}141-860 \mathrm{~B}- \\
2 \mathrm{H}-5.117-119 \\
5 \mathrm{H}-5,110-112 \\
6 \mathrm{H}-6,47-49 \\
10 \times-\mathrm{CC}, 14-16 \\
30 \times-2.87-89 \\
32 \mathrm{X}-2.52-54\end{array}$ & $\begin{array}{r}8.57 \\
37.00 \\
47.37 \\
68.84 \\
243.82 \\
262.77\end{array}$ & $\begin{array}{l}3.5 \\
7.4 \\
2.8 \\
1.0 \\
1.6 \\
0.8\end{array}$ & $\begin{array}{r}23.3 \\
40.6 \\
21.0 \\
15.3 \\
5.7 \\
7.1\end{array}$ & $\begin{array}{r}43.1 \\
21.3 \\
38.3 \\
18.4 \\
20.3 \\
7.2\end{array}$ & $\begin{array}{l}15.3 \\
11.4 \\
16.4 \\
27.6 \\
27.7 \\
34.1\end{array}$ & $\begin{array}{r}9.4 \\
16.3 \\
15.0 \\
30.6 \\
34.1 \\
43.7\end{array}$ & $\begin{array}{r}5.4 \\
3.0 \\
6.5 \\
7.1 \\
10.6 \\
7.1\end{array}$ & $\begin{array}{l}200 \\
200 \\
200 \\
120 \\
120 \\
120\end{array}$ & $\begin{array}{l}\text { Normally graded sand bed with scoured lower contant } \\
\text { Silty sand } \\
\text { Massive fine to medium sand } \\
\text { Inverse to normally graded fine sand (thin section) } \\
\text { Sandy siltstone (thin section) } \\
\text { Thin layers of sand to sandy siltstone (thin section) }\end{array}$ \\
\hline $\begin{array}{l}141-861 \mathrm{C}- \\
3 \mathrm{H}-2.12-14 \\
7 \mathrm{H}-5.121-123 \\
10 \mathrm{H}-4.136-138\end{array}$ & $\begin{array}{l}14.12 \\
57.71 \\
76.86\end{array}$ & $\begin{array}{l}8.8 \\
2.5 \\
4.1\end{array}$ & $\begin{array}{l}32.4 \\
17.0 \\
36.0\end{array}$ & $\begin{array}{l}18.6 \\
50.0 \\
24.3\end{array}$ & $\begin{array}{l}17.2 \\
17.0 \\
15.8\end{array}$ & $\begin{array}{l}19.6 \\
11.5 \\
17.6\end{array}$ & $\begin{array}{l}3.4 \\
2.0 \\
2.2\end{array}$ & $\begin{array}{l}200 \\
200 \\
200\end{array}$ & $\begin{array}{l}\text { Silty sand interval in silty clay } \\
\text { Normally graded silty sand interval in silty clay } \\
\text { Laminated fine sand }\end{array}$ \\
\hline $\begin{array}{l}141-862 \mathrm{~B}- \\
2 \mathrm{X}-1.44-46\end{array}$ & 17.94 & 0.9 & 19.4 & 21.2 & 17.1 & 33.6 & 7.8 & 200 & Layer of trough cross-bedded sandstone \\
\hline $\begin{array}{l}141-863 \mathrm{~A}- \\
2 \mathrm{H}-2,15-17 \\
3 \mathrm{H}-2,55-58 \\
8 \mathrm{X}-3,72-74 \\
17 \mathrm{X}-\mathrm{CC}, 22-24 \\
26 \mathrm{X}-\mathrm{CC}, 17-19 \\
27 \mathrm{X}-1,24-26 \\
28 \mathrm{X}-\mathrm{CC}, 25-27\end{array}$ & $\begin{array}{r}10.25 \\
20.15 \\
69.22 \\
153.27 \\
231.07 \\
249.44 \\
260.55\end{array}$ & $\begin{array}{r}7.0 \\
10.9 \\
1.6 \\
2.9 \\
2.8 \\
2.8 \\
6.1\end{array}$ & $\begin{array}{r}26.6 \\
33.2 \\
7.2 \\
16.2 \\
31.8 \\
24.1 \\
29.5\end{array}$ & $\begin{array}{l}31.3 \\
24.8 \\
36.0 \\
21.4 \\
22.3 \\
24.5 \\
25.2\end{array}$ & $\begin{array}{r}4.7 \\
22.8 \\
23.2 \\
27.6 \\
17.1 \\
14.6 \\
9.8\end{array}$ & $\begin{array}{r}24.3 \\
7.4 \\
30.4 \\
30.0 \\
23.2 \\
26.0 \\
28.0\end{array}$ & $\begin{array}{l}6.1 \\
0.9 \\
1.6 \\
1.9 \\
2.8 \\
8.0 \\
1.4\end{array}$ & $\begin{array}{l}200 \\
200 \\
120 \\
200 \\
200 \\
200 \\
200\end{array}$ & $\begin{array}{l}\text { Sand bed in silty clay to clayey silt section } \\
\text { Laminated fine- to medium-grained sand bed } \\
\text { Clayey silt to clayey sand interbed (thin section) } \\
\text { Massive silty sandsone } \\
\text { Silty sandstone to sandstone } \\
\text { Laminated fine sandstone } \\
\text { Massive sandstone }\end{array}$ \\
\hline $\begin{array}{l}141-863 \mathrm{~B}- \\
4 \mathrm{X}-1,31-33 \\
7 \mathrm{~N}-\mathrm{CC} .7-9 \\
15 \mathrm{R}-1.85-89\end{array}$ & $\begin{array}{l}326.21 \\
357.39 \\
416.05\end{array}$ & $\begin{array}{l}7.1 \\
5.5 \\
4.5\end{array}$ & $\begin{array}{l}28.4 \\
41.8 \\
43.2\end{array}$ & $\begin{array}{l}20.9 \\
19.4 \\
19.7\end{array}$ & $\begin{array}{l}15.2 \\
11.9 \\
16.9\end{array}$ & $\begin{array}{l}23.2 \\
16.4 \\
11.8\end{array}$ & $\begin{array}{l}5.2 \\
5.0 \\
3.9\end{array}$ & $\begin{array}{l}200 \\
200 \\
200\end{array}$ & $\begin{array}{l}\text { Fine sandstone (steeply dipping domain) } \\
\text { Sandstone interbeds (steeply dipping domain) } \\
\text { Sandstone with altered glass (steeply dipping domain) }\end{array}$ \\
\hline
\end{tabular}

Note: $\mathrm{I}=$ highly vesicular (colorless), $\mathrm{II}=$ vesicular (colorless to light brownish), $\mathrm{III}=$ vesicular $($ brownish). IV = slightly vesicular $($ brownish), $\mathrm{V}=$ blocky with few vesicles (brownish to blackish), $\mathrm{VI}=$ blocky (blackish).

$57 \%$ ) in composition. The colorless, highly vesicular clasts are all dacite to rhyolite, whereas brownish to blackish vesicular to blocky clasts are generally andesite to basaltic andesite in composition, respectively. Table 3 demonstrates that the silicic, vesicle-rich clast component is abundant in upper Pleistocene record (Sites 860,861 , and 863 ; see Fig. 2 for ages).

The source volcanoes were intermediate, or occasionally silicic, in composition and the volcanic debris correlate geochemically with high-alumina basaltic andesites, andesites and dacites of the calcalkaline volcanoes in Chile (Vergara and Munizaga, 1974; LopezEscobar et al., 1977). More crustal involvement is evident in arcmagmatism because high proportions of silicic volcaniclasts occur within the sediment material uphole. This may be evidence that there was a shift in the chemistry of arc volcanism related to ridge subduction beneath the Chilean continental margin. Other changes in the conditions of magma genesis, however, could have occurred. Some of the volcanic debris in the lower portions of Leg 141 sediments derived perhaps also from more local Pliocene fore-arc volcanic centers on the Taitao Peninsula (e.g., Forsythe et al., 1986; Forsythe and Prior, 1992; Marsaglia et al., this volume). The volcanic products have compositions ranging from basalts, basaltic andesite to dacite with lesser rhyolite (Forsythe et al., 1986).

\section{Primary Ash Layers}

Two major modes of marine ash layers occur along the trench slope of the Chile margin: (1) thin layers of tephra from subaerial eruptions, and (2) subaqueous basaltic to basaltic andesitic black ash beds which are intercalated with fine-grained deep-water sediments. SEM microstructure analysis permits the recognition of two endmembers of volcanic glass: highly vesicular to vesicular (Type I) with thin vesicle walls or smooth fluid-form surfaces (P1. 2, Figs. 1-4, and equant, blocky (Type VI) with planar or curviplanar surfaces (Pl. 2, Figs. 7-9).
The marine fallout ash layers are usually thin, relatively well sorted and normally graded or massive with sharp bases. The vesicular to highly vesicular glass within the fallout ash layers consists of subaerially transported particles which settled on water and finally were deposited on the bottom, possibly hundreds of $\mathrm{km}$ from their source (e.g., Fisher, 1984; Fisher and Schmincke, 1984). The highly vesicular glass types are characteristic of highly explosive Plinian to Ultra-Plinian eruptions (Walker, 1973; Wright et al., 1980; Heiken and Wohletz, 1985). One distinct ash layer, more than $22 \mathrm{~cm}$ thick and composed of $80 \%-90 \%$ colorless pumiceous glass, was recovered from Hole 860 at $144.70-144.92$ mbsf (PI. 2, Figs. 1-4). No primary ash layers were observed at either Site 859 or Site 863 . Site 861 had volcanic ash layers at three different intervals: ash at $66.26 \mathrm{mbsf}$ is light-colored, normally graded and almost $7 \mathrm{~cm}$ thick, containing pumiceous, highly vesicular, colorless, slightly corroded glass fragments (Pl. 2, Figs. 5 and 6); that at 184 mbsf is a very thin lens of light gray volcanic lapilli, and that at $347.30 \mathrm{mbsf}$ is a clast concentration of medium gray tuff consisting of vesicular to highly vesicular colorless glass fragments.

Thin ash beds with equant, blocky glass fragments with very rare or no vesicles and of colors from dark brown to black are abundant at Site 862 (Pl. 2, Figs. 7-9). Two volcanic lapilli layers of coarse, sand-sized particles of blocky, black vitric glass were noted in Subunit IA (Section 141-862A-1H-3, 68-72 cm, and Section 141-862A-2H-1, $105-106 \mathrm{~cm}$ ), while Subunit IB contains as many as ten ash layers with dispersed coarse sand to pebble-size black, blocky volcanic glass, intercalated with fine-grained sediments (Fig. 4). The basal conglomerate observed in Subunit IC also contains abundant black volcanic glass fragments. This black glass greatly resembles the glass margins of the underlying volcanic rocks of Unit II (Shipboard Scientific Party, 1992d). The blocky fragments were formed as a result of rapid quenching of the subaqueous lava by sea water, forming deep-sea hyaloclastic particles (Heiken and Wohletz, 1985; Cas and Wright, 1987). Fisher and Schmincke (1984) called this type of glass spallation or spalling 
Table 3. Representative individual analyses of single volcanic glass grains from sand-sized fraction ( $>0.063 \mathrm{~mm})$ of Leg 141 coarse sediments and primary ash layers by SEM/EDS at Institute of Electron Optics, University of Oulu.

\begin{tabular}{|c|c|c|c|c|c|c|c|c|c|c|c|c|}
\hline $\begin{array}{l}\text { Core, section. } \\
\text { interval }(\mathrm{cm})\end{array}$ & $\begin{array}{l}\text { Depth } \\
\text { (mbsf) }\end{array}$ & $\mathrm{SiO}_{2}$ & $\mathrm{TiO}_{2}$ & $\mathrm{Al}_{2} \mathrm{O}_{3}$ & $\mathrm{FeO}^{*}$ & $\mathrm{MnO}$ & $\mathrm{MgO}$ & $\mathrm{CaO}$ & $\mathrm{Na}_{2} \mathrm{O}$ & $\mathrm{K}_{2} \mathrm{O}$ & Total & Comment \\
\hline $\begin{array}{l}\text { 141-859B- } \\
16 R-4.13-15 \\
16 R-4.13-15\end{array}$ & $\begin{array}{l}259.23 \\
259.23\end{array}$ & $\begin{array}{l}52.91 \\
50.46\end{array}$ & $\begin{array}{l}1.69 \\
1.48\end{array}$ & $\begin{array}{l}15.43 \\
16.78\end{array}$ & $\begin{array}{l}8.05 \\
8.48\end{array}$ & $\begin{array}{l}0.23 \\
0.17\end{array}$ & $\begin{array}{l}3.90 \\
5.27\end{array}$ & $\begin{array}{l}7.05 \\
8.47\end{array}$ & $\begin{array}{l}4.37 \\
3.82\end{array}$ & $\begin{array}{l}1.47 \\
0.84\end{array}$ & $\begin{array}{l}95.10 \\
95.77\end{array}$ & $\begin{array}{l}\text { Vesicular } \\
\text { Blocky with few vesicles }\end{array}$ \\
\hline $\begin{array}{l}141-860 \mathrm{-}- \\
2 \mathrm{H}-5,117-119 \\
2 \mathrm{H}-5,117-119 \\
2 \mathrm{H}-5.117-119 \\
5 \mathrm{H}-5,110-112 \\
5 \mathrm{H}-5.110-112 \\
5 \mathrm{H}-5.110-112 \\
5 \mathrm{H}-5.110-112 \\
5 \mathrm{H}-5.110-112 \\
5 \mathrm{H}-5,110-112 \\
19 \mathrm{X}-6.12-13 \\
19 \mathrm{X}-6.12-13 \\
19 \times-6.12-13 \\
19 X-6.12-13 \\
19 \mathrm{X}-6.12-13\end{array}$ & $\begin{array}{r}8.57 \\
8.57 \\
8.57 \\
37.00 \\
37.00 \\
37.00 \\
37.00 \\
37.00 \\
37.00 \\
156.60 \\
156.60 \\
156.60 \\
156.60 \\
156.60\end{array}$ & $\begin{array}{l}60.62 \\
59.97 \\
55.81 \\
62.79 \\
65.51 \\
58.95 \\
54.04 \\
54.17 \\
54.73 \\
61.50 \\
67.17 \\
63.40 \\
67.44 \\
70.12\end{array}$ & $\begin{array}{l}1.78 \\
1.80 \\
1.71 \\
0.62 \\
0.64 \\
1.27 \\
1.41 \\
1.63 \\
1.51 \\
0.48 \\
0.56 \\
0.51 \\
0.56 \\
0.38\end{array}$ & $\begin{array}{l}15.97 \\
16.16 \\
16.43 \\
13.84 \\
14.99 \\
14.91 \\
15.39 \\
16.23 \\
15.51 \\
13.65 \\
14.55 \\
14.20 \\
15.01 \\
13.31\end{array}$ & $\begin{array}{l}8.76 \\
6.51 \\
8.33 \\
2.49 \\
2.27 \\
4.61 \\
7.52 \\
7.76 \\
7.33 \\
2.17 \\
2.20 \\
2.32 \\
2.32 \\
1.56\end{array}$ & $\begin{array}{l}0.00 \\
0.26 \\
0.00 \\
0.17 \\
0.00 \\
0.00 \\
0.00 \\
0.00 \\
0.19 \\
0.00 \\
0.00 \\
0.00 \\
0.00 \\
0.00\end{array}$ & $\begin{array}{l}2.56 \\
2.40 \\
4.30 \\
0.36 \\
0.48 \\
1.42 \\
3.63 \\
3.25 \\
3.68 \\
0.75 \\
0.60 \\
0.73 \\
0.76 \\
0.36\end{array}$ & $\begin{array}{l}5.52 \\
4.14 \\
8.05 \\
0.92 \\
1.09 \\
3.34 \\
6.85 \\
6.48 \\
6.89 \\
2.78 \\
2.67 \\
2.79 \\
3.09 \\
1.81\end{array}$ & $\begin{array}{l}4.10 \\
3.99 \\
4.01 \\
3.52 \\
3.71 \\
4.19 \\
3.85 \\
4.52 \\
4.06 \\
3.40 \\
2.56 \\
2.60 \\
2.58 \\
3.12\end{array}$ & $\begin{array}{l}1.66 \\
3.05 \\
1.19 \\
2.92 \\
2.84 \\
2.24 \\
1.21 \\
1.40 \\
1.20 \\
1.59 \\
1.67 \\
1.54 \\
1.65 \\
2.19\end{array}$ & $\begin{array}{r}100.95 \\
98.27 \\
99.91 \\
87.62 \\
91.54 \\
90.93 \\
93.89 \\
95.44 \\
95.10 \\
86.30 \\
91.98 \\
88.07 \\
93.41 \\
92.84\end{array}$ & $\begin{array}{l}\text { Slightly vesicular } \\
\text { Slightly vesicular } \\
\text { Slightly vesicular } \\
\text { Highly vesicular (Plate I. Figs. 1,2) } \\
\text { Highly vesicular } \\
\text { Vesicular (Plate 1, Fig. 3) } \\
\text { Vesicular } \\
\text { Vesicular } \\
\text { Slightly vesicular } \\
\text { (A) Highly vesicular (Plate 2. Figs. 1-3) } \\
\text { (A) Highly vesicular } \\
\text { (A) Highly vesicular } \\
\text { (A) Highly vesicular } \\
\text { (A) Highly vesicular }\end{array}$ \\
\hline $\begin{array}{l}141-861 \mathrm{C}- \\
3 \mathrm{H}-2,12-14 \\
3 \mathrm{H}-2,12-14 \\
3 \mathrm{H}-2,12-14 \\
3 \mathrm{H}-2,12-14 \\
7 \mathrm{H}-5,121-123 \\
7 \mathrm{H}-5,12 \mathrm{I}-123 \\
7 \mathrm{H}-5,121-123 \\
7 \mathrm{H}-5,12 \mathrm{I}-123 \\
7 \mathrm{H}-5,121-123 \\
7 \mathrm{H}-5,12 \mathrm{I}-123 \\
7 \mathrm{H}-5,121-123 \\
8 \mathrm{H}-5,26-28 \\
8 \mathrm{H}-5,26-28 \\
8 \mathrm{H}-5,26-28\end{array}$ & $\begin{array}{l}14.12 \\
14.12 \\
14.12 \\
14.12 \\
57.71 \\
57.71 \\
57.71 \\
57.71 \\
57.71 \\
57.71 \\
57.71 \\
66.26 \\
66.26 \\
66.26\end{array}$ & $\begin{array}{l}65.82 \\
62.18 \\
67.07 \\
58.43 \\
56.01 \\
54.21 \\
57.73 \\
55.75 \\
54.93 \\
53.54 \\
53.05 \\
66.99 \\
70.87 \\
61.00\end{array}$ & $\begin{array}{l}1.17 \\
1.45 \\
1.20 \\
1.86 \\
1.63 \\
1.84 \\
1.95 \\
1.91 \\
2.02 \\
1.85 \\
2.18 \\
0.21 \\
0.15 \\
0.16\end{array}$ & $\begin{array}{l}16.48 \\
16.09 \\
16.43 \\
16.81 \\
15.95 \\
15.59 \\
15.01 \\
15.71 \\
15.43 \\
16.15 \\
14.97 \\
12.98 \\
12.36 \\
23.07\end{array}$ & $\begin{array}{r}4.23 \\
5.58 \\
3.82 \\
7.04 \\
6.28 \\
8.95 \\
7.29 \\
6.95 \\
8.92 \\
8.43 \\
10.14 \\
2.03 \\
0.83 \\
0.44\end{array}$ & $\begin{array}{l}0.00 \\
0.22 \\
0.00 \\
0.23 \\
0.24 \\
0.19 \\
0.17 \\
0.21 \\
0.00 \\
0.19 \\
0.20 \\
0.00 \\
0.00 \\
0.00\end{array}$ & $\begin{array}{l}1.22 \\
2.06 \\
0.92 \\
2.92 \\
2.52 \\
3.39 \\
2.33 \\
2.62 \\
3.17 \\
4.32 \\
3.49 \\
0.43 \\
0.00 \\
0.00\end{array}$ & $\begin{array}{l}2.63 \\
4.06 \\
2.06 \\
6.10 \\
5.21 \\
6.52 \\
4.84 \\
5.61 \\
6.38 \\
7.94 \\
7.03 \\
2.37 \\
1.35 \\
6.80\end{array}$ & $\begin{array}{l}3.53 \\
3.63 \\
4.06 \\
3.20 \\
3.46 \\
3.92 \\
3.60 \\
3.52 \\
4.06 \\
3.86 \\
4.03 \\
2.03 \\
2.65 \\
5.57\end{array}$ & $\begin{array}{l}2.66 \\
2.09 \\
2.92 \\
1.70 \\
1.71 \\
1.42 \\
1.83 \\
1.68 \\
1.47 \\
1.09 \\
1.37 \\
1.55 \\
2.16 \\
0.68\end{array}$ & $\begin{array}{l}97.74 \\
97.36 \\
98.46 \\
98.29 \\
93.01 \\
96.01 \\
94.74 \\
93.95 \\
96.57 \\
97.38 \\
96.45 \\
88.58 \\
90.36 \\
97.72\end{array}$ & $\begin{array}{l}\text { Vesicular (bubble-wall shard) } \\
\text { Vesicular (Plate I. Fig. 5) } \\
\text { Slightly vesicular } \\
\text { Vesicular } \\
\text { Slightly vesicular } \\
\text { Blocky with few vesicles } \\
\text { Vesicular (bubble-wall shard) } \\
\text { Slightly vesicular } \\
\text { Vesicular (bubble-wall shard) } \\
\text { Slightly vesicular } \\
\text { Slightly vesicular } \\
\text { (A) Highly vesicular (Plate 2. Figs, 4-5) } \\
\text { (A) Highly vesicular (altered) } \\
\text { (A) Highly vesicular (altered) }\end{array}$ \\
\hline 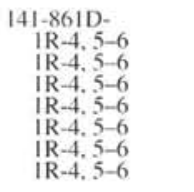 & $\begin{array}{l}347.30 \\
347.30 \\
347.30 \\
347.30 \\
347.30 \\
347.30 \\
347.30\end{array}$ & $\begin{array}{l}60.44 \\
59.80 \\
68.70 \\
68.32 \\
69.39 \\
59.72 \\
59.97\end{array}$ & $\begin{array}{l}0.57 \\
0.38 \\
0.26 \\
0.30 \\
0.24 \\
0.63 \\
0.62\end{array}$ & $\begin{array}{l}17.67 \\
22.86 \\
14.55 \\
14.91 \\
14.58 \\
17.18 \\
17.15\end{array}$ & $\begin{array}{l}3.85 \\
1.84 \\
1.15 \\
0.92 \\
1.06 \\
4.43 \\
3.88\end{array}$ & $\begin{array}{l}0.00 \\
0.00 \\
0.32 \\
0.25 \\
0.32 \\
0.20 \\
0.00\end{array}$ & $\begin{array}{l}1.21 \\
0.41 \\
0.00 \\
0.00 \\
0.00 \\
1.58 \\
1.40\end{array}$ & $\begin{array}{l}3.82 \\
6.29 \\
0.27 \\
0.38 \\
0.27 \\
3.81 \\
3.89\end{array}$ & $\begin{array}{l}4.03 \\
7.11 \\
2.69 \\
2.43 \\
1.99 \\
3.31 \\
3.26\end{array}$ & $\begin{array}{l}1.65 \\
0.65 \\
4.35 \\
4.43 \\
4.51 \\
2.00 \\
1.84\end{array}$ & $\begin{array}{l}93.23 \\
99.34 \\
92.28 \\
91.94 \\
92.35 \\
92.87 \\
92.01\end{array}$ & $\begin{array}{l}\text { (A) Highly vesicular } \\
\text { (A) Highly vesicular } \\
\text { (A) Highly vesicular } \\
\text { (A) Highly vesicular } \\
\text { (A) Highly vesicular } \\
\text { (A) Vesicular } \\
\text { (A) Vesicular }\end{array}$ \\
\hline $\begin{array}{l}14 \mathrm{I}-862 \mathrm{~A}- \\
2 \mathrm{H}-1.104-106 \\
2 \mathrm{H}-1.104-106 \\
2 \mathrm{H}-1.104-106 \\
2 \mathrm{H}-1.104-106 \\
2 \mathrm{H}-1.104-106\end{array}$ & $\begin{array}{l}6.44 \\
6.44 \\
6.44 \\
6.44 \\
6.44\end{array}$ & $\begin{array}{l}50.57 \\
50.63 \\
52.35 \\
51.78 \\
51.73\end{array}$ & $\begin{array}{l}1.41 \\
1.24 \\
1.17 \\
1.24 \\
1.08\end{array}$ & $\begin{array}{l}15.81 \\
16.24 \\
16.56 \\
16.84 \\
16.99\end{array}$ & $\begin{array}{l}7.87 \\
7.90 \\
6.75 \\
7.07 \\
7.06\end{array}$ & $\begin{array}{l}0.00 \\
0.22 \\
0.00 \\
0.19 \\
0.00\end{array}$ & $\begin{array}{l}7.76 \\
7.92 \\
8.35 \\
8.08 \\
7.97\end{array}$ & $\begin{array}{l}11.08 \\
11.13 \\
10.00 \\
10.38 \\
10.55\end{array}$ & $\begin{array}{l}2.86 \\
2.78 \\
2.88 \\
2.97 \\
2.99\end{array}$ & $\begin{array}{l}0.10 \\
0.12 \\
0.39 \\
0.25 \\
0.29\end{array}$ & $\begin{array}{l}97.47 \\
98.17 \\
98.44 \\
98.80 \\
98.68\end{array}$ & $\begin{array}{l}\text { (A) Blocky (Plate 2, Figs. 6-8) } \\
\text { (A) Blocky } \\
\text { (A) Blocky } \\
\text { (A) Blocky } \\
\text { (A) Blocky }\end{array}$ \\
\hline $\begin{array}{l}141-862 B- \\
2 X-1,44-46 \\
2 X-1,44-46\end{array}$ & $\begin{array}{l}17.94 \\
17.94\end{array}$ & $\begin{array}{l}71.25 \\
71.15\end{array}$ & $\begin{array}{l}0.33 \\
0.32\end{array}$ & $\begin{array}{l}13.81 \\
14.44\end{array}$ & $\begin{array}{l}1.54 \\
1.67\end{array}$ & $\begin{array}{l}0.00 \\
0.00\end{array}$ & $\begin{array}{l}0.34 \\
0.42\end{array}$ & $\begin{array}{l}1.05 \\
1.21\end{array}$ & $\begin{array}{l}2.56 \\
2.87\end{array}$ & 3.26 & $\begin{array}{l}94.13 \\
95.29\end{array}$ & $\begin{array}{l}\text { Vesicular (bubble-wall shard) } \\
\text { Vesicular (bubble-wall shard) }\end{array}$ \\
\hline $\begin{array}{r}141-863 \mathrm{~A}- \\
17 X-C C .22-24 \\
17 X-C C .22-24 \\
17 X-C C .22-24 \\
17 X-C C, 22-24 \\
28 X-C C .25-27 \\
28 X-C C .25-27 \\
28 X-C C .25-27 \\
28 X-C C .25-27\end{array}$ & $\begin{array}{l}153.27 \\
153.27 \\
153.27 \\
153.27 \\
260.55 \\
260.55 \\
260.55 \\
260.55\end{array}$ & $\begin{array}{l}62.73 \\
64.17 \\
65.88 \\
61.61 \\
69.86 \\
59.21 \\
60.74 \\
62.46\end{array}$ & $\begin{array}{l}1.40 \\
0.83 \\
0.85 \\
0.91 \\
0.52 \\
1.71 \\
1.62 \\
1.83\end{array}$ & $\begin{array}{l}15.84 \\
15.05 \\
15.47 \\
15.61 \\
15.04 \\
15.85 \\
15.88 \\
16.14\end{array}$ & $\begin{array}{l}4.88 \\
3.20 \\
2.85 \\
4.12 \\
1.80 \\
6.43 \\
5.86 \\
7.52\end{array}$ & $\begin{array}{l}0.00 \\
0.16 \\
0.23 \\
0.00 \\
0.00 \\
0.00 \\
0.00 \\
0.18\end{array}$ & $\begin{array}{l}1.51 \\
0.73 \\
0.67 \\
1.13 \\
0.55 \\
2.36 \\
1.89 \\
2.35\end{array}$ & $\begin{array}{l}3.66 \\
1.73 \\
1.65 \\
2.96 \\
1.66 \\
4.80 \\
4.09 \\
4.74\end{array}$ & $\begin{array}{l}3.70 \\
3.35 \\
2.65 \\
1.92 \\
1.79 \\
2.24 \\
4.24 \\
4.10\end{array}$ & $\begin{array}{l}2.29 \\
2.90 \\
2.86 \\
1.70 \\
3.15 \\
1.77 \\
2.28 \\
2.25\end{array}$ & $\begin{array}{r}96.01 \\
92.12 \\
93.11 \\
89.96 \\
94.38 \\
94.39 \\
96.59 \\
101.55\end{array}$ & $\begin{array}{l}\text { Slightly vesicular } \\
\text { Blocky with few vesicles } \\
\text { Vesicular (bubble-wall shard) } \\
\text { Vesicular (bubble-wall shard) } \\
\text { Vesicular } \\
\text { Vesicular } \\
\text { Vesicular (bubble-wall shard) } \\
\text { Vesicular (bubble-wall shard) }\end{array}$ \\
\hline
\end{tabular}

Notes: $\mathrm{FeO}^{*}=$ total iron as $\mathrm{FeO}$. Volcanic glass grains from primary ash layerst marked as $\mathrm{A}$ in comments.

shards, being related to the cooling contraction of pillows of sheet lavas or the expansion of growing pillow tubes.

\section{Major-element Composition of the Pyroclasts}

The range of composition of the individual volcanic glass fragments in the fallout ash layers on the TAS diagram is from dacite to rhyolite (Table 3 and Fig. 5). The volcanic glass grains of the fallout ashes belong to the calc-alkaline fractionation series (Fig. 5). Most analyses of the glass fragments within each ash layer are relatively coherent; however, the samples from Site 861 at 66.26 and 347.3 mbsf are most heterogeneous. SEM/EDS investigations reveal variable degrees of alteration in these ash layers (Sample 141-861C-8H$5,26-28 \mathrm{~cm}$, and Sample 141-861D-1R-4, 5-6 cm). The glass fragments have low $\mathrm{MgO}$ contents and enrichments in either $\mathrm{Al}_{2} \mathrm{O}_{3}$ or $\mathrm{SiO}_{2}$ have occurred relative to compositions of rhyolitic ash particles (e.g., at Site 860). Plate 2, Figs. 5 and 6 show the corroded to slightly altered, highly vesicular glass fragments of Sample 141$861 \mathrm{C}-8 \mathrm{H}-5,26-28 \mathrm{~cm}$. The dacitic to rhyolitic glasses as two groups in Sample 141-861D-1R-4, 5-6 cm, (Fig. 5) may originate from different sources, or they may be co-genetic in a single volcanic event (e.g., Bitschene et al., 1985; Pouclet et al., 1986).

The black ash beds at Site 862 show a composition of basalt to basaltic andesite on the TAS diagram and more of an arc tholeiitic character than trends of a typical calc-alkaline suite in the $\mathrm{K}_{2} \mathrm{O}-\mathrm{SiO}_{2}$ variation diagram (Table 3 and Fig. 5). The glass fragments have low $\mathrm{K}_{2} \mathrm{O}$ and $\mathrm{TiO}_{2}$ contents and $\mathrm{FeO} / \mathrm{MgO}$ of about 1 (Table 3). The major-element compositions of the underlying basalts of Unit II showing $\mathrm{SiO}_{2}$ values ranging from $48 \%$ to $52 \%$, relatively high $\mathrm{MgO}$ contents $(8.0 \%-8.6 \%)$ with $\mathrm{K}_{2} \mathrm{O}$ values less than $0.5 \%$ (Shipboard Scientific Party, 1992d) much resemble the glass compositions of Site 862 ash beds. The thin black ash beds intercalated with fine-grained sediments are closely related to the growth of the Taitao Ridge by local near-trench volcanism. 

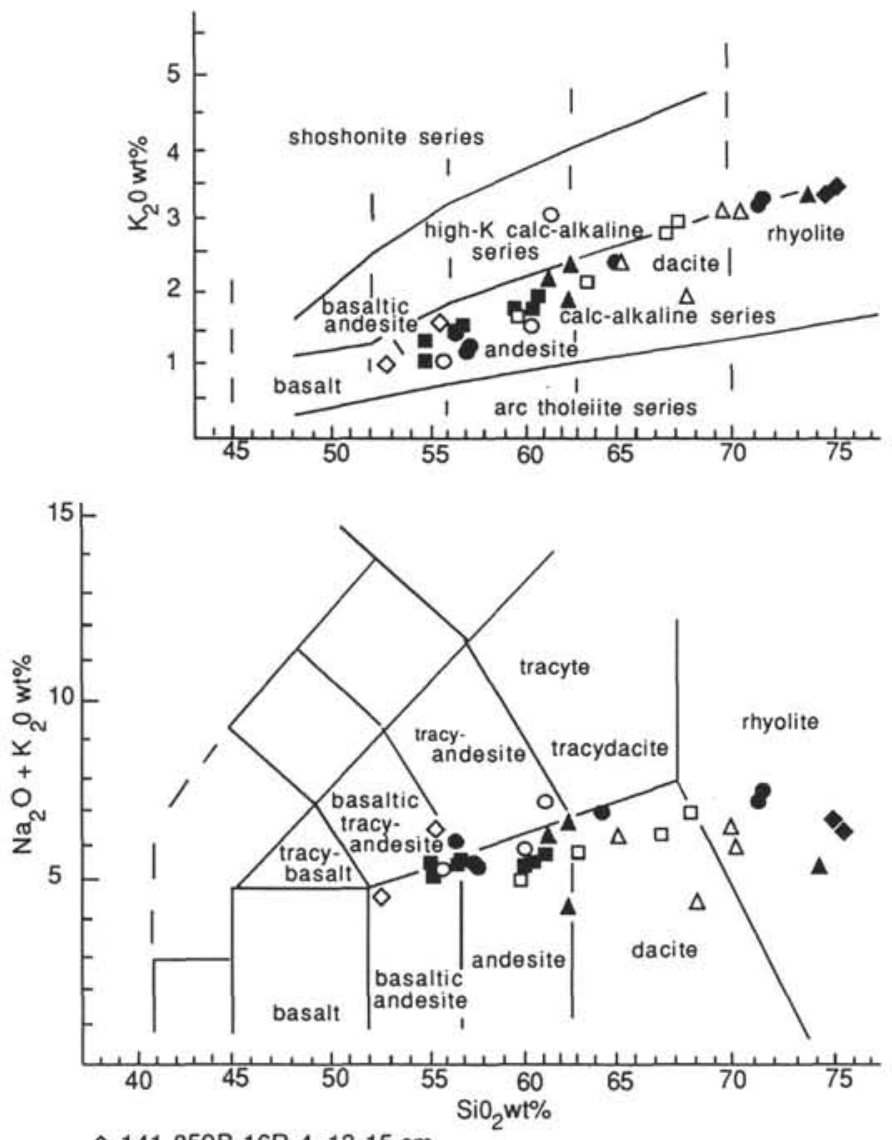

$\diamond 141-859 \mathrm{~B}-16 \mathrm{R}-4,13-15 \mathrm{~cm}$

O $141-860 \mathrm{~B}-2 \mathrm{H}-5,117-119 \mathrm{~cm}$

- $141-860 \mathrm{~B}-5 \mathrm{H}-5,110-112 \mathrm{~cm}$

ㅁ $141-861 \mathrm{C}-3 \mathrm{H}-2,12-14 \mathrm{~cm}$

- $141-861 \mathrm{C}-7 \mathrm{H}-5,121-123 \mathrm{~cm}$

141-862B-2X-1, 44-46 cm

$\triangle 141-863 \mathrm{~A}-17 \mathrm{X}-\mathrm{CC}, 22-24 \mathrm{~cm}$

A $141-863 \mathrm{~A}-28 \mathrm{X}-\mathrm{CC}, 25-27 \mathrm{~cm}$

Figure 3. Total alkali vs. silica (TAS) plot and $\mathrm{K}_{2} \mathrm{O}-\mathrm{SiO}_{2}$ variation diagram for all the representative volcanic glasses analyzed from the sand-sized fraction of the Leg 141 sediments. Classification in TAS from Le Bas et al. (1986) and lines on the $\mathrm{K}_{2} \mathrm{O}$ divisions mark the suite boundaries from Peccerillo and Taylor (1976).

\section{ORIGIN OF VOLCANOGENIC SEDIMENTS}

The trench-slope basin in the Chile margin in the vicinity of the Chile Triple Junction was dominated by a terrigenous sediment input and received siliciclastics, including volcaniclastics, in significant amounts. The southern Andes were glaciated since about $4.6 \mathrm{Ma}$, and the icefields expanded repeatedly between 2.4 and $1.2 \mathrm{Ma}$ (Rabassa and Clapperton, 1990), providing suitable conditions for glacially influenced deposition on the trench slope (Fig. 6). It is generally the case that during glacial maxima the glaciers influence sedimentation over huge portions of the continental margins and adjacent deep sea because to global lowstands of sea level, accordingly deep-sea fan sedimentation is generally temporarily halted or diminished during the highstands of sea level (e.g., Shanmugam and Moiola, 1982, 1988).

\section{Eruptions, Transport, and Sedimentation}

SEM microstructural analysis of some of the glassy volcaniclastic grains demonstrates a mixed provenance of arc- and to some extent forearc-derived volcaniclastics with a distribution which is related to the transportation by turbidity currents. The volcaniclastic record

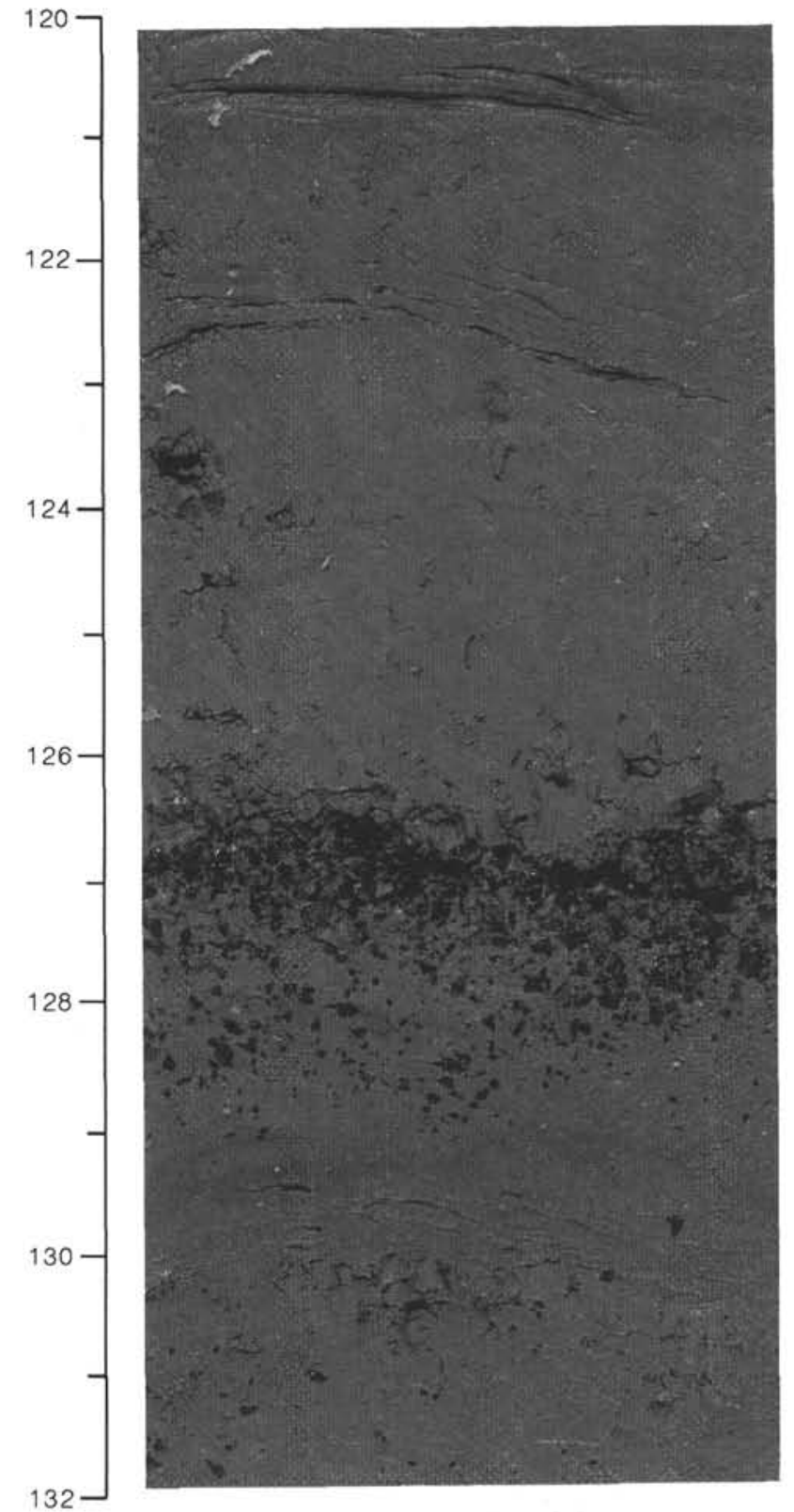

Figure 4. A layer of black, blocky volcanic glass in claystone from Hole 862. The glass horizon has a gradational lower contact and a relatively sharp upper contact. A thin, laminated, silty bed occurs just $2 \mathrm{~cm}$ below the ash layer. Section 141-862B-2X-2, 120-132 cm.

apparently reveals the evolutionary trends that occur during spreading-ridge subduction. The predominant source of glassy volcaniclastics was an extensive, north-south-trending, acidic-intermediate calcalkaline volcanic belt in Chile (Fig. 6).

The main volcanic belt is located approximately $200 \mathrm{~km}$ inland of the Peru-Chile trench and is divided into northern $(\mathrm{SVZ}=$ Southern Volcanic Zone) and southern (AVZ = "Austral" Volcanic Zone) zones with an arc gap of up to $300 \mathrm{~km}$ between them (Forsythe and Prior, 1992; Fig. 3). The SVZ is approximately $70 \mathrm{~km}$ wide and is composed of up to 40 Holocene and 20 or more Plio-Pleistocene stratovolcanoes. The Hudson Volcano is the southernmost and likely source of the glassy volcanic debris (Marsaglia et al., this volume). The gap is inferred to be directly related to the existence of a slab window produced by the spreading-ridge subduction (Cande and Leslie, 1986; 

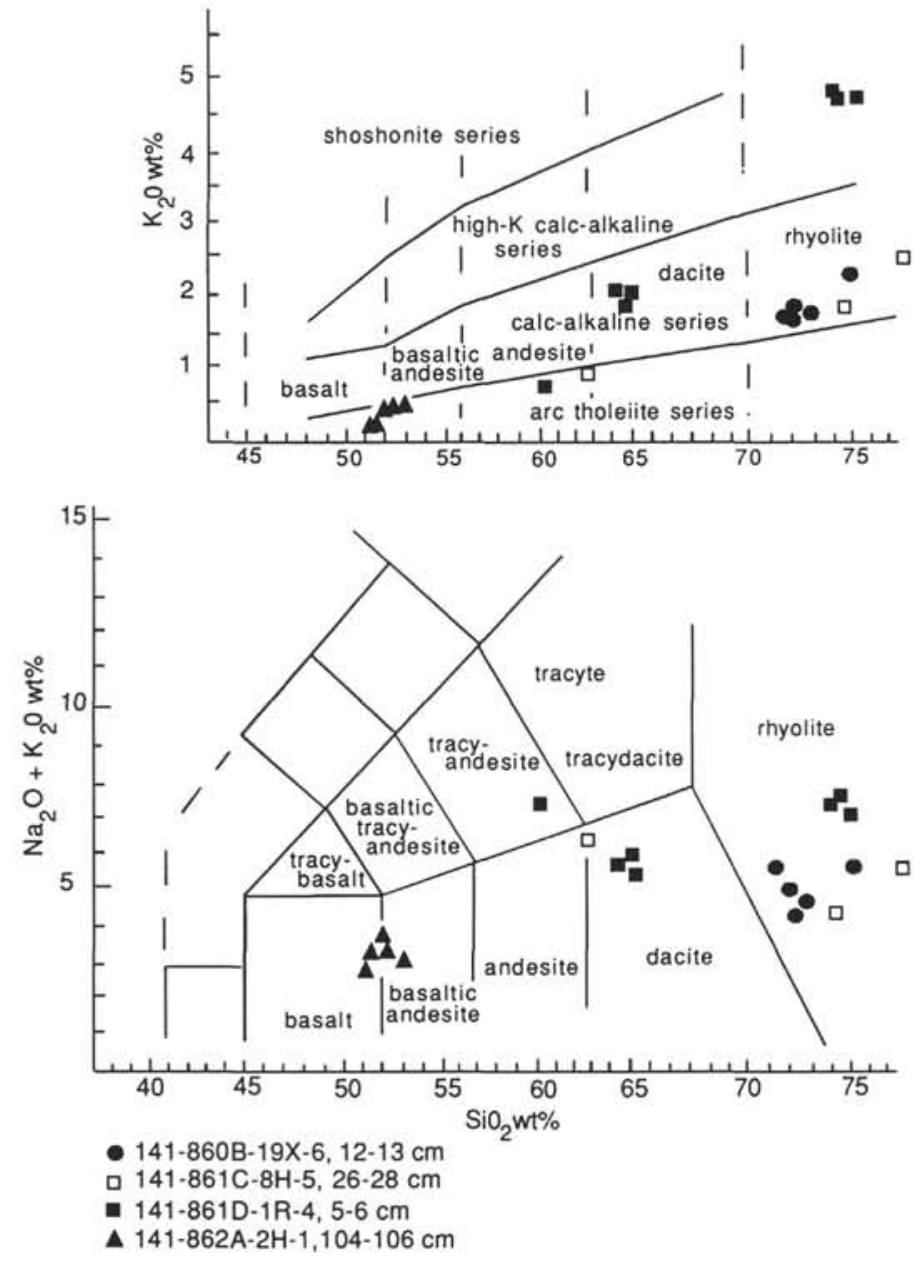

Figure 5. Total alkali vs. silica (TAS) plot and $\mathrm{K}_{2} \mathrm{O}-\mathrm{SiO}_{2}$ variation diagram for all the representative volcanic glasses analyzed from the Leg 141 primary ash layers. Classification in TAS from Le Bas et al. (1986) and lines on the $\mathrm{K}_{2} \mathrm{O}$ divisions mark the suite boundaries from Peccerillo and Taylor (1976).

Forsythe and Nelson, 1985). The slow down of arc volcanism in the southern part of the SVZ apparently occurred during progressive spreading-ridge subduction in the Chile Triple Junction. This is inferred from the observation that the volcaniclastic component in the sediments is more abundant throughout the Pliocene to lower Pleistocene sandy portions and is absent or more restricted during the upper Pleistocene. The silicic, vesicle-rich clast component, abundant upsection in the Pleistocene record, is mostly concentrated in the sandy turbidites. The silicic pyroclastics indicate increased crustal involvement. The deposition of sparse pumiceous lapilli-ash layers at the present sites after strong explosive activity is probably related more to the direction of the winds than directly to the evolution of the arc volcanism prior to spreading-ridge subduction. Some volcanic debris in the lower portions of Leg 141 sediments may derive also from more local Pliocene forearc volcanic centers on the Taitao Peninsula (e.g., Forsythe et al., 1986; Forsythe and Prior, 1992; Marsaglia et al., this volume), whereas the abundant thin basaltic to basaltic andesitic ash layers at Site 862 indicate quench fragmentation during relatively local subaqueous arc tholeiitic-type volcanism near-trench in the Taitao Ridge related to the spreading-ridge subduction and incipient rifting along the Taitao Fracture Zone (Fig. 6).

Large quantities of terrigenous sediment were transported to the trench slope of the Chile margin by turbidity currents and related gravity flows during glacial maxima (e.g., Thornburg and Kulm, 1987b). Larger amounts of secondary volcaniclastic sediments would thereby be delivered to the trench slope more frequently. When the shelf areas were ice covered (e.g., during the glacial maxima in the early Pleistocene; Rabassa and Clapperton, 1990), they were subjected to glacial erosion, and some distal subaerial ash could have been even deposited directly over the ice sheet and later mixed with other sediment components and directly transported to deep sea environments (Fig. 6). This and cold climate could be mechanisms for the formation of secondary volcaniclastics with very fresh and angular, vesicular to highly vesicular volcanic glass grains. North of the triple junction, the continental divide comprises a series of Pliocene and Pleistocene volcanic centers, but to the south the Andes are dominated by deeper crustal complexes of magmatic and metamorphic rocks (Forsythe and Prior, 1992), providing good opportunities for the mixing of deeper crustal material (i.e., magmatic and metamorphic rock detritus) with volcaniclastics under glacial and meltwater influence (Shipboard Scientific Party, 1992c) propagated by uplift and erosion of Andean Cordillera and Taitao Peninsula during migration of the Chile Triple Junction.

\section{CONCLUSIONS}

These investigations were intended to provide information on the processes of volcaniclastic sedimentary input and general sediment transport in a trench-slope environment. The sediment composition recovered on Leg 141 is greatly influenced by the glacial phases in the southern Andes and the volcanic activity along the Andean arc effected by spreading-ridge subduction.

1. The main origin of the secondary glassy volcaniclastic fragments is the Andean volcanic arc itself and the sparse pyroclastic layers mostly originated from Plinian to Ultra-Plinian acidic explosive activity.

2. It can be demonstrated that the black, vitric ash layers of nearby areas of the Taitao Ridge are related to subaqueous near-trench volcanism linked with spreading-ridge subduction and incipient rifting along the Taitao Fracture Zone.

3. The glacial influence in the Chile margin adjacent to the Chile Triple Junction was temporary and with increasing sediment supply, larger amounts of volcaniclastics were delivered to the trench slope more frequently.

4. Volcanic activity progressively ceased in part of Chile during the Pliocene-Pleistocene because of spreading ridge subduction in the Chile Triple Junction, leaving its own information in the volcanogenic sediment component of the trench slope. The sparse tephra came from the volcanic arc areas by means of aerial currents related to the volcano-tectonic history of the Andean arc.

\section{ACKNOWLEDGMENTS}

I would like to thank K. Marsaglia, R. Forsythe, N. Lindsley-Griffin, and D. Prior for discussions regarding the sediment interpretations. I thank the staff of the Institute of Electron Optics, especially Raija Peura, for helping in the SEM/EDS and FESEM work, and I thank Malcolm Hicks for correcting the English of the manuscript. $\mathrm{T}$. Vallier and A. Wetzel provided constructive and helpful reviews which substantially improved the original manuscript. Participation in ODP Leg 141 and this research was supported by the Natural Sciences Council of the Academy of Finland.

\section{REFERENCES}

Bangs, N., Cande, S.C., Lewis, S.D., and Miller, J., 1992. Structural framework of the Chile Margin at the Chile Ridge collision zone. In Behrmann,

\footnotetext{
Abbreviations for names of organizations and publications in ODP reference lists follow the style given in Chemical Abstracts Service Source Index (published by American Chemical Society).
} 
J.H., Lewis, S.D., Musgrave, R.J., et al., Proc. ODP, Init. Repts., 141: College Station, TX (Ocean Drilling Program), 11-21.

Bitschene, P.R., Schmincke, H.-U., and Viereck, L., 1989. Cenozoic ash layers on the Vøring Plateau (ODP Leg 104). In Eldholm, O., Thiede, J., Taylor, E., et al., Proc. ODP, Sci. Results, 104: College Station, TX (Ocean Drilling Program), 357-366.

Cande, S.C., and Leslie, R.B., 1986. Late Cenozoic tectonics of the southern Chile Trench. J. Geophys. Res., 91:471-496.

Cande, S.C., Leslie, R.B., Barra, J.C., and Hobart, M., 1987. Interaction between the Chile Ridge and Chile Trench: geophysical and geothermal evidence. Jour. Geophys. Res., 92:495-520.

Cas, R.A.F., and Wright, J.V., 1987. Volcanic Successions: Modern and Ancient: London (Allen and Unwin).

Desprairies, A., Maury, R.C., Joron, J.-L., Bohn, M., and Tremblay, P., 1989. Distribution, chemical characteristics, and origin of ash layers from ODP Leg 104, Vøring Plateau, North Atlantic. In Eldholm, O., Thiede, J., Taylor. E., et al., Proc. ODP, Sci. Results, 104: College Station, TX (Ocean Drilling Program), 337-356.

Fisher, R.V., 1984. Submarine volcaniclastic rocks. In Kokelaar, B.P., and Howells, M.F. (Eds.), Marginal Basin Geology: Volcanic and Associated Sedimentary Processes in Modern and Ancient Basins. Geol. Soc. Spec. Publ. London, 16:5-28.

Fisher, R.V., and Schmincke, H.-U., 1984. Pyroclastic Rocks: New York (Springer Verlag).

Forsythe, R., and Nelson, E., 1985. Geological manifestations of ridge collision: evidence from the Golfo de Penas-Taitao Basin, southern Chile. Tectonics, 4:447-495.

Forsythe, R., and Prior, D., 1992. Cenozoic continental geology of South America and its relations to the evolution of the Chile Triple Junction. In Behrmann, J.H., Lewis, S.D., Musgrave, R.J., et al., Proc. ODP, Init. Repts., 141: College Station, TX (Ocean Drilling Program), 23-31.

Forsythe, R.D., Nelson, E.P., Carr, M.J., Kaeding, M.E., Herve, M., Mpodozis, C., Soffia, J.M., and Harambour, S., 1986. Pliocene near-trench magmatism in southern Chile: a possible manifestation of ridge collision. Geology, 14:23-27.

Fujioka, K., Matsuo, Y., Nishimura, A., Koyama, M., and Rodolfo, K.S., 1992. Tephras of the Izu-Bonin forearc (Sites 787, 792, and 793). In Taylor, B., Fujioka, K., et al., Proc. ODP, Sci. Results, 126: College Station, TX (Ocean Drilling Program), 47-74.

Heiken, G., 1972. Morphology and petrology of volcanic ashes. Geol Soc. Am. Bull., 83:1961-1987.

Heiken, G., and Wohletz, K., 1974. An Atlas of Volcanic Ash. Smithsonian Contrib. Earth Sci., 12.

1985. Volcanic Ash: Berkeley (Univ. of California Press).

Le Bas, M.J., Le Maitre, R.W., Streckeisen, A., and Zanettin, B., 1986. A chemical classification of volcanic rocks based on the total alkali-silica diagram. J. Petrol., 27:745-750.

Le Bas, M.J., Le Maitre, R.W., and Woolley, A.R., 1992. The construction of the total alkali-silica chemical classification of volcanic rocks. Mineral. Petrol., 46:1-22.

Lopez-Escobar, L., Frey, F.A., and Vergara, M., 1977. Andesites and high-alumina basalts from the central-south Chile High Andes: geochemical evidence bearing on their petrogenesis. Contrib. Mineral. Petrol., 63:199-228.

Marshak, R.S., and Karig, D.E., 1977. Triple junctions as a cause for anomalously near-trench igneous activity between the trench and volcanic arc. Geology, 5:233-236.

Nishimura, A., Rodolfo, K.S., Koizumi, A., Gill. J., and Fujioka, K., 1992. Episodic deposition of Pliocene-Pleistocene pumice from the lzu-Bonin Arc, Leg 126. In Taylor, B., Fujioka, K., et al., Proc. ODP, Sci. Results, 126: College Station, TX (Ocean Drilling Program), 3-21.

Peccerillo, A., and Taylor, S.R., 1976. Geochemistry of Eocene calc-alkaline volcanic rocks from the Kastamonu area, northern Turkey. Contrib. Mineral. Petrol., 58:63-81.
Pickering, K., Stow, D., Watson, M., and Hiscott, R., 1986. Deep-water facies, processes and models: a review and classification scheme for modern and ancient sediments. Earth Sci. Rev., 23:75-174.

Pickering, K.T., Hiscott, R., and Hein, F.J., 1989. Deep-marine Environments: Clastic Sedimentation and Tectonics: London (Unwin Hyman),

Pouclet, A., Cambrey, H., Cadet, J.-P., Bourgois, J., and De Wever, P., 1990. Volcanic ash from Leg 112 off Peru. In Suess, E., von Huene, R., et al., Proc. ODP, Sci. Results, 112: College Station, TX (Ocean Drilling Program), 465-480.

Rabassa, J., and Clapperton, C.M., 1990. Quaternary glaciations of the southern Andes. Quat. Sci. Rev., 9:153-174.

Rodolfo, K.S., Solidum, R.U., Nishimura, A., Matsuo, Y., and Fujioka, K., 1992. Major-oxide stratigraphy of glass shards in volcanic ash layers of the Izu-Bonin Arc-backarc sites (Sites 788/789 and 790/791). In Taylor, B., Fujioka, K., et al., Proc. ODP, Sci. Results, 126: College Station, TX (Ocean Drilling Program), 505-517.

Shanmugam, G., and Moiola, R.J., 1982. Eustatic control of turbidites and winnowed turbidites. Geology, 10:231-235.

, 1988. Submarine fans: characteristics, models, classification, and reservoir potential. Earth-Sci. Rev., 24:383-428.

Shipboard Scientific Party, 1992a. Site 859. In Behrmann, J.H., Lewis, S.D. Musgrave, R.J., et al., Proc. ODP, Init. Repts., 141: College Station, TX (Ocean Drilling Program), 75-157.

, 1992b. Site 860. In Behrmann, J.H., Lewis, S.D., Musgrave, R.J., et al., Proc. ODP, Init. Repts., 141: College Station, TX (Ocean Drilling Program), 159-238.

1992c. Site 861. In Behrmann, J.H., Lewis, S.D., Musgrave, R.J., et al., Proc. ODP, Init. Repts., 141: College Station, TX (Ocean Drilling Program), 239-299.

, 1992d. Site 862. In Behrmann, J.H., Lewis, S.D., Musgrave, R.J., et al., Proc. ODP, Init. Repts., 141: College Station, TX (Ocean Drilling Program), 301-341.

, 1992e. Site 863. In Behrmann, J.H., Lewis, S.D., Musgrave, R.J., et al., Proc. ODP, Init. Repts., 141: College Station, TX (Ocean Drilling Program), 343-446.

Thornburg, T.M., and Kulm, L.D., 1987a. Sedimentation in the Chile Trench: depositional morphologies, lithofacies, and stratigraphy. Geol. Soc. Am. Bull., 98:33-52.

1987b. Sedimentation in the Chile Trench: petrofacies and provenance. J. Sediment. Petrol., 57:55-74.

Thornburg, T.M., Kulm, L.D., and Hussong, D.M., 1990. Submarine-fan development in the southern Chile Trench: a dynamic interplay of tectonics and sedimentation. Geol. Soc. Am. Bull., 102:1658-1650.

Underwood, M.B., and Bachman, S.G., 1982. Sedimentary facies associations within subduction complexes. In Leggett, J.K. (Ed.), Trench-Forearc Geology: Sedimentation and Tectonics on Modern and Ancient Active Plate Margins. Geol. Soc. Spec. Publ. London, 10:537-550.

Vergara, M., and Munizaga, F., 1974. Age and evolution of upper Cenozoic volcanism in central-south Chile. Bull. Geol. Soc. Am., 85:603-606.

Walker, G.P.L., 1973. Explosive volcanic eruptions-a new classification scheme. Geol. Rundsch., 62:431-446.

Wright, J.V., Smith, A.L., and Self, S., 1980. A working terminology of pyroclastic deposits. J. Volcanol. Geotherm. Res., 8:315-336.

Wohletz, K.H., 1983. Mechanisms of hydrovolcanic pyroclast formation: grain size, scanning electron microscopy, and experimental studies. J. Volcanol. Geotherm. Res., 17:31-63.

Date of initial receipt: 19 July 1993

Date of acceptance: 6 December 1993

Ms 141SR-007 


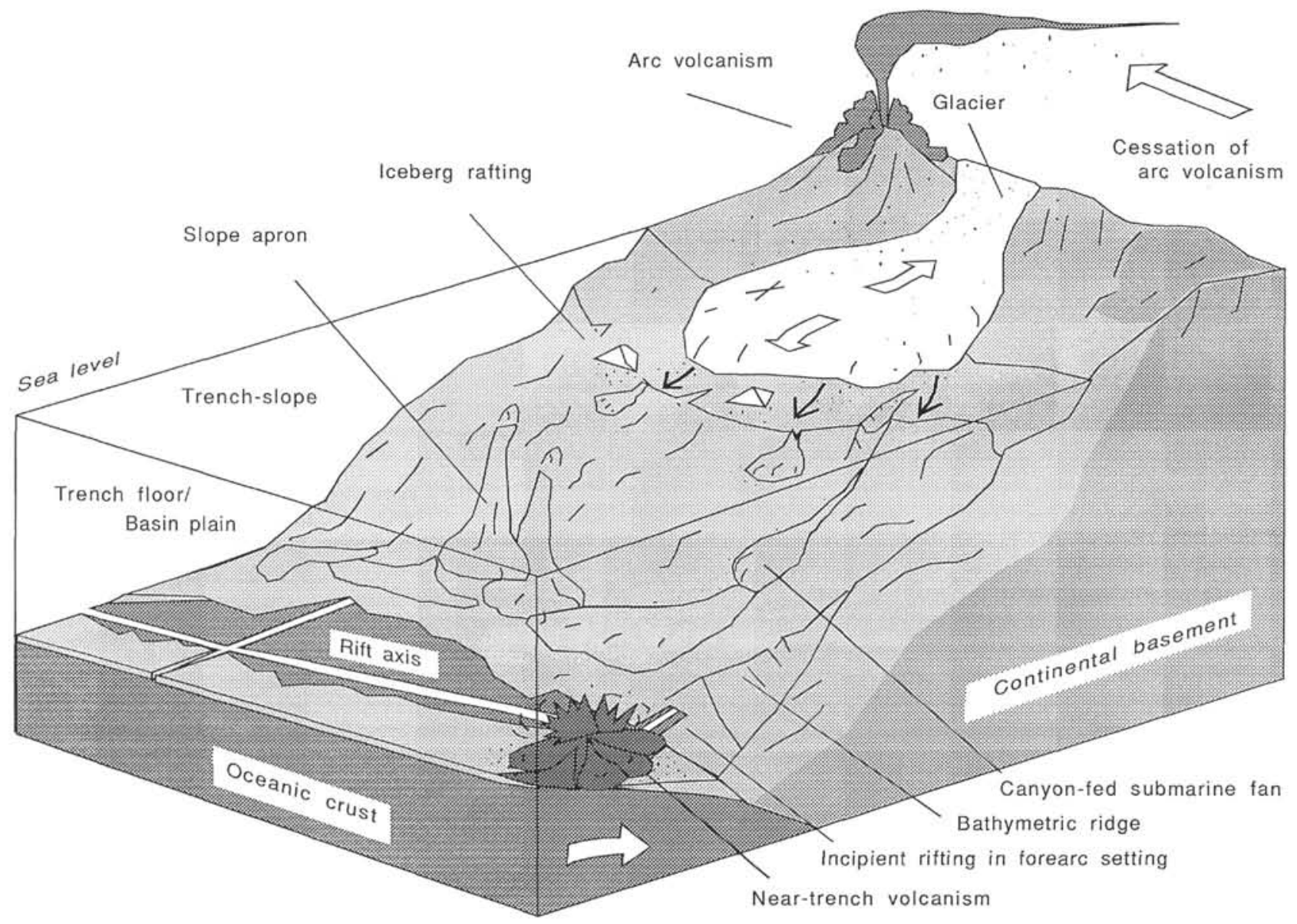

Figure 6. Schematic block diagram showing the depositional pathways of primary and secondary volcaniclastics on the trench slope of the Chile margin in the vicinity of the Chile Ridge collision zone. 

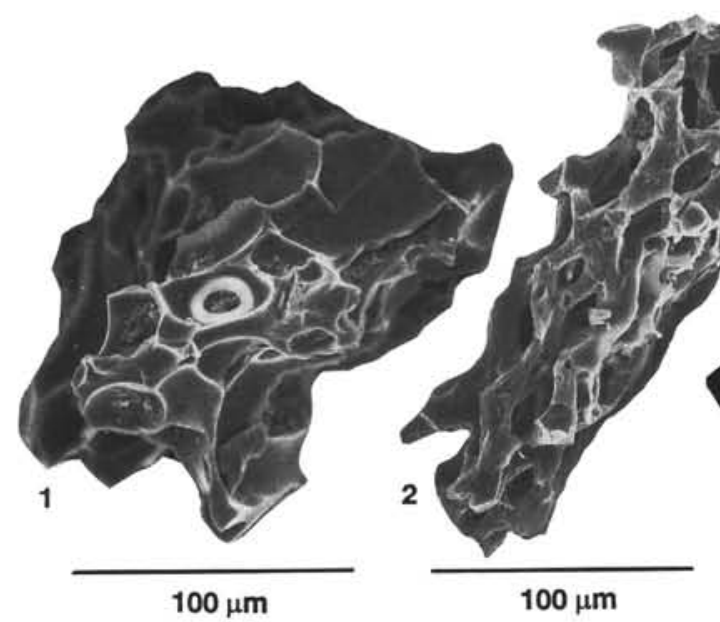

$100 \mu \mathrm{m}$
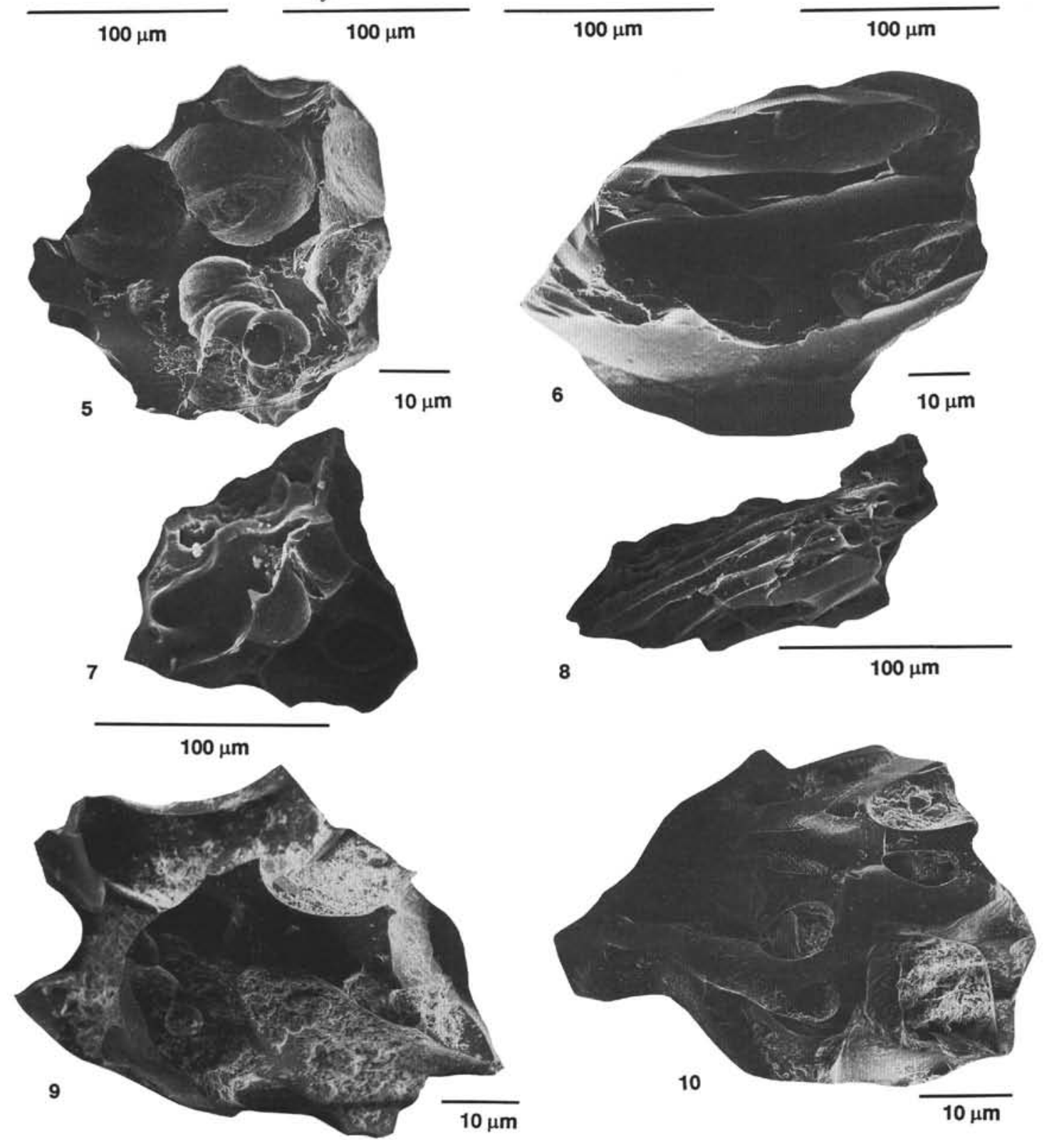

Plate 1. SEM pictures of typical volcanic glass grains of Leg 141 coarse-grained sediments. 1-2. Highly vesicular to reticulate rhyolitic glass grains (Type I) in silty sand. Sample 141-860B-5H-5, 110-112 cm. 3. Plate-like glass grain with fluidal texture. Sample 141-860B-5H-5, 110-112 cm. 4. Blocky glass grain with few vesicles and microlitic texture (Type V). Sample 141-860-5H-5, 110-112 cm. 5-6. Slightly rounded, vesicular, andesitic to dacitic glass grains with rounded to elongated vesicles (Type II and Type III). Sample 141-860B-5H-5, 110-112 cm. 7-8. Vesicular glass grains with blocky to elongated shapes. Sample 141-860C-6H-6, 47-49 cm. 9. Vesicular, slightly corroded dacitic glass grain with blocky shape. Sample 141-861C-3H-2, 12-14 cm. 10. Vesicular glass grain with rounded vesicles. Sample 141-363A-3H-2, 55-58 cm. 

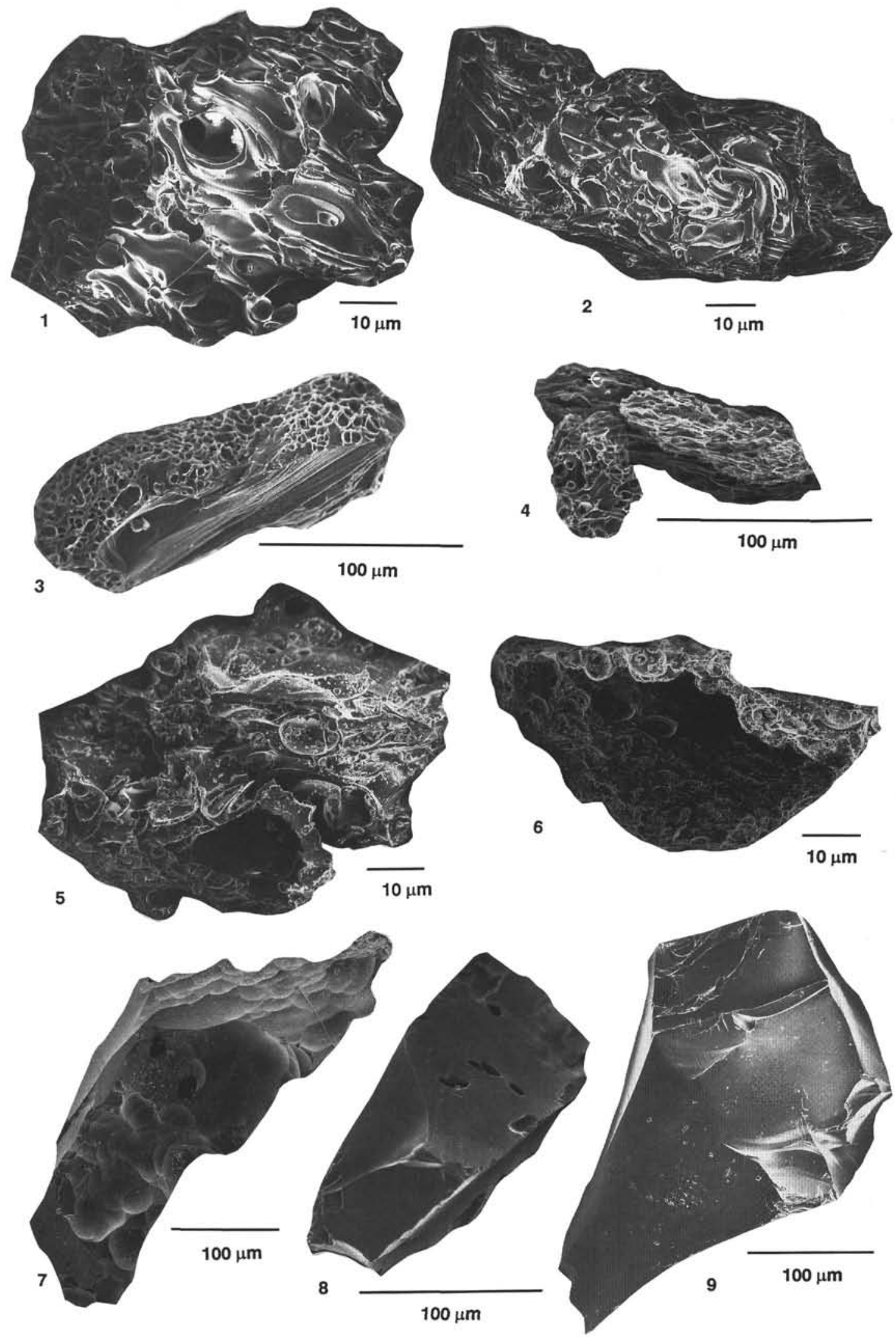

Plate 2. SEM pictures of typical glass fragments of Leg 141 primary ash layers. 1-4. Highly vesicular dacitic to rhyolitic glass fragments (Type I) in light gray lapilli and ash layer. Fragments may show smooth, fluid-form surfaces or universally thin vesicle walls. Sample 141-860B-19X-6, 12-13 cm. 5-6. Corroded to slightly altered, highly vesicular dacitic to rhyolitic glass fragments in light gray, normally graded lapilli to ash layer. 141-861C-8H-5, 26-28 cm. 7-9. Blocky, low-K, basaltic to basaltic andesitic glass fragments (Type VI) in thin ash beds intercalated with claystones. Grain shapes characterized by planar or curviplanar surfaces. Sample 141-862A-3H-1, 24-26 cm. 